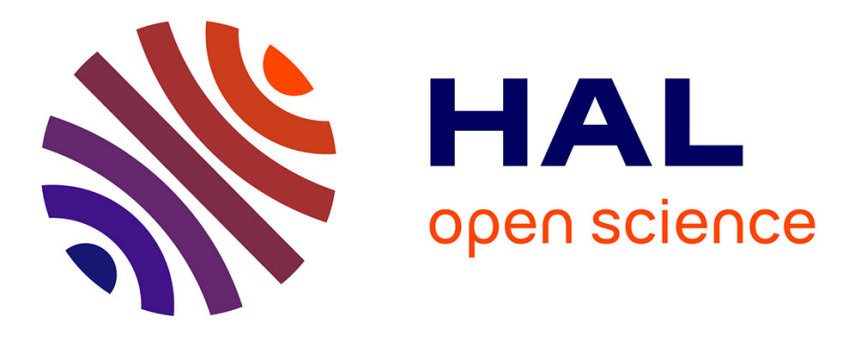

\title{
ERH proteins: connecting RNA processing to tumorigenesis?
}

Marc Graille, Mathieu Rougemaille

\section{To cite this version:}

Marc Graille, Mathieu Rougemaille. ERH proteins: connecting RNA processing to tumorigenesis?.

Current Genetics, 2020, 66 (4), pp.689-692. 10.1007/s00294-020-01065-z . hal-02503603

\section{HAL Id: hal-02503603 \\ https://hal-polytechnique.archives-ouvertes.fr/hal-02503603}

Submitted on 10 Nov 2020

HAL is a multi-disciplinary open access archive for the deposit and dissemination of scientific research documents, whether they are published or not. The documents may come from teaching and research institutions in France or abroad, or from public or private research centers.
L'archive ouverte pluridisciplinaire HAL, est destinée au dépôt et à la diffusion de documents scientifiques de niveau recherche, publiés ou non, émanant des établissements d'enseignement et de recherche français ou étrangers, des laboratoires publics ou privés. 


\title{
ERH proteins: connecting RNA processing to tumorigenesis?
}

\section{Marc Graille1 and Mathieu Rougemaille ${ }^{2}$}

${ }^{1}$ Laboratoire de Biologie Structurale de la Cellule (BIOC), CNRS, Ecole polytechnique, Institut Polytechnique de Paris, F-91128 Palaiseau, France

2 Université Paris-Saclay, CEA, CNRS, Institute for Integrative Biology of the Cell (I2BC), 91198, Gif-sur-Yvette, France

\begin{abstract}
With the development of -omics approaches, the scientific community is now submerged by a wealth of information that can be used to analyze various parameters: the degree of protein sequence conservation, protein 3D structures as well as RNA and protein expression levels in various benign and tumor tissues, during organism development or upon exposure to chemicals such as endocrine disrupters. However, if such information can be used to identify genes with potentially important biological function, additional studies are needed to deeply characterize their cellular function in model organisms. Here, we discuss the case of such a gene: ERH, encoding a highly conserved homodimeric protein found in unicellular eukaryotes, plants and metazoan, of yet unknown biological function, which might be linked to mRNA metabolism and that is emerging as important for cell migration and metastasis.
\end{abstract}

\section{Keywords}

Sequence conservation / Homodimer / Unknown function / cancer / mRNA processing

Correspondence should be addressed to MG (marc.graille@polytechnique.edu) and MR (mathieu.rougemaille@i2bc.paris-saclay.fr). 
High degree of protein sequence conservation rhymes with important biological function. Indeed, due to evolutionary pressure, proteins that fulfill crucial functions such as histones, exhibit only limited mutations, which most often cluster to regions that are not strategic for their biological functions. In the light of those, the eukaryotic ERH proteins should then play key roles for biological processes in metazoan and plants. Indeed, the sequence of ERH proteins in human, mouse and frog are strictly identical and differ by only one amino acid in zebrafish. Yet, ERH's biological function still remains largely obscure although links with physiopathologies such as cancer are emerging.

Initially, the ERH gene (for enhancer of the rudimentary) was identified to exacerbate the truncated wings phenotype observed upon mutation of the rudimentary gene in fruit-fly hence its name (Wojcik, et al. 1994). Very early, the crystal structures of several metazoan ERH proteins (100-120 amino acids long) were determined, revealing an overall organization as butterfly-shaped homodimers, which might be involved in the recruitment of protein partners (Arai, et al. 2005, Jin, et al. 2007, Wan, et al. 2005). Later, ERH was shown to affect various cellular processes including cell cycle progression, mRNA transcription and splicing as well as DNA replication and repair (Figure, left panel; (Fujimura, et al. 2012, Pogge von Strandmann, et al. 2001, Weng, et al. 2012, Weng and Luo 2013)). Consistent with this, ERH interacts with RNA Pol II-associated factors, subunits of the spliceosome, components of the DNA replication and repair machineries, and the microprocessor complex, involved in miRNA processing (Banko, et al. 2013, Kavanaugh, et al. 2015, Tsubota and Phillips 2016, Weng and Luo 2013). Some of these processes have recently been shown to be interconnected (Mikolaskova, et al. 2018). ERH localizes to the nucleus and is enriched in foci corresponding to nuclear speckles, sites of spliceosome assembly (Banko, et al. 2013). However, the physiological relevance of some interactions remains unknown and the involvement of ERH in specific processes might well be the consequence of a primary function in mRNA splicing. CENP-E and ATR mRNAs, which encode for a kinetochore protein important for chromosome segregation and a major kinase involved in DNA replication and repair respectively, are indeed improperly spliced upon ERH knockdown. This was proposed to account for the defects in chromosome alignment during mitosis and in genome stability (Kavanaugh, et al. 2015, Nakagawa and Okita 2019, Weng, et al. 2012, Weng, et al. 2015).

Despite the lack of mechanistic insights, ERH now clearly appears as a factor influencing cell migration and carcinogenesis. For instance, ERH expression is significantly increased in breast, ovarian and liver tumor cells as compared to related normal cells (Weng, et al. 2015, Zafrakas, et al. 2008, Zhang, et al. 2020). ERH is also important for survival of cancer cells harboring mutations in the KRAS small GTPase, a potent oncogene activating several effector pathways triggering cell cycle and mitosis (Weng, et al. 2012). Similarly, ERH depletion inhibits migration, proliferation and invasiveness of bladder urothelial carcinoma and ovarian cancer cells (Pang, et al. 2019, Zhang, et al. 2020). However, despite some pioneer studies, the precise molecular function of this family of protein in plants and metazoan remains to be dissected to clearly understand ERH's role in cell proliferation and cancer.

Interestingly, more distant ERH orthologues, sharing around 30\% sequence identity with the human protein, are found in unicellular eukaryotes such as the fission yeast Schizosaccharomyces pombe and related fungi. Recent studies on $S$. pombe Erh1 have unveiled important functional insights that might guide future studies on ERH proteins (Figure, right panel). Erh1 associates with the YTH family RNA-binding protein Mmil to form the EMC complex (Erh1-Mmil complex) that targets meiosis-specific transcripts for degradation by the nuclear exosome during mitosis (Harigaya, et al. 2006, Sugiyama, et al. 2016) . EMC is also essential for the assembly of facultative het- 
erochromatin at a subset of meiotic genes (Hiriart, et al. 2012, Xie, et al. 2019, Zofall, et al. 2012). Noteworthy, formation of heterochromatin is important to maintain chromosome integrity and genome stability (Nakagawa and Okita 2019). One surprising feature of Erh1 is that not only it suppresses the meiotic program in vegetative cells, but it also promotes meiosis progression, unveiling an important role in developmental transitions (Hazra, et al. 2020, Sugiyama, et al. 2016). Recently, the crystal structure of EMC revealed its organization as an heterotetramer, whereby two Mmi1 molecules associate simultaneously with an Erh1 homodimer (Xie, et al. 2019). A linear motif in Mmil contacts a region spanning both Erh1 monomers and disruption of this Erh1-Mmi1 interaction results in impaired meiotic mRNA degradation and defective heterochromatin formation at meiotic genes (Xie, et al. 2019).

ERH and Erh1 homodimers assemble in a very similar manner and are formed by the contribution of hydrophobic residues highly conserved from human to fungi. We have very recently tested the importance of homodimer formation on Erh1 biological functions and found that a mutant preventing homodimerization without affecting the structure of monomers, phenocopies the deletion of the erh $1+$ gene, i.e. disruption of meiotic gene silencing during mitosis and impaired meiosis progression (Hazra, et al. 2020). Surprisingly, although the Mmil interaction site on Erh1 dimer involves residues from both monomers, precluding formation of Erh1 homodimer does not abolish the Erh1-Mmi1 interaction in vivo (Hazra, et al. 2020). This indicates that Erh1 self-association and interaction with Mmil are both critical for EMC function in S. pombe (Xie, et al. 2019). Beyond the homodimerization surface, the Erh1 region forming Mmil binding groove also displays a significant degree of conservation, suggesting that in human ERH, the corresponding region might also recognize linear motifs on protein partners. Search for motifs similar to the Mmil signature recognized by Erh1 did not reveal obvious putative partners for human ERH. However, interaction networks mediated by short linear motifs are prone to rewiring during evolution. In response to few mutations, signatures important for interactions can disappear from one protein family while a related sequence may emerge in other proteins that participate in the same cellular process in another organism (Jonas and Izaurralde 2013). Proteomic approaches aimed at comparing interaction partners between wild-type and mutant ERH (i.e. mutated in the region corresponding to Erh1 area involved in Mmil binding) should bring insightful information about the role(s) of the protein. Whether ERH dimerization also contributes to assemble larger complexes, as illustrated by EMC in $S$. pombe, remains an intriguing question for future studies. Finally, biochemical analyses are needed to apprehend the functional consequences of increased ERH expression in cancer cells.

In conclusion, ERH proteins are highly conserved but yet mysterious proteins that appear to play crucial roles in cell biology and cancer. Although some studies performed in human cells or in $S$. pombe have enlightened some properties of ERH/Erh1 proteins in RNA metabolism, this family of proteins definitely requires further studies aimed at characterizing its precise molecular function in metazoan and plant cells. Furthermore, due to its prevalent role in progression and invasiveness of cancer cells, this protein can be an excellent target for the development of anti-cancer drugs. Either ERH homodimer formation or ERH interaction with proteins yet to be identified by the region corresponding to Mmil binding site on Erh1 might be Achille's heels that could be targeted for the development of small molecules impeding either self-association or protein-protein interactions.

\section{Acknowledgments}

This work was supported by Ecole polytechnique, the Institut de Biologie Intégrative de la Cellule, the Centre National pour la Recherche Scientifique and the Agence Nationale pour la Recherche [grants ANR-16-CE11-0003 to M.G and ANR-16-CE12-0031-01 to M.R.]. 


\section{Legend to figure:}

\section{Cellular roles of ERH/Erh1 homodimers.}

Left : Human ERH associates with multiple factors to regulate various cellular functions, including RNA processing and DNA replication, thereby promoting cell division and genome stability. How ERH contributes to tumorigenicity remains to be elucidated. By analogy to the Erh1-Mmi1 complex in fission yeast, we speculate that formation of ERH homodimer might play a key role in forming a composite surface to recognize linear motifs on protein partners.

Right : During mitosis, S. pombe Erh1 homodimer associates with two Mmi1 proteins to form the EMC. Through its YTH domain, Mmil recognizes specific motifs (highlighted in red) within meiotic mRNAs that are clustered into larger regions known as DSR (for Determinant of Selective Removal). Once assembled, EMC recruits the nuclear exosome to mediate meiotic mRNA degradation. Formation of Erh1 homodimer is also essential for meiosis progression.

\section{References}

Arai R, Kukimoto-Niino M, Uda-Tochio H, Morita S, Uchikubo-Kamo T, Akasaka R, Etou Y, Hayashizaki Y, Kigawa T, Terada T, Shirouzu M, Yokoyama S (2005) Crystal structure of an enhancer of rudimentary homolog $(\mathrm{ERH})$ at 2.1 Angstroms resolution. Protein science : a publication of the Protein Society 14: 1888-1893 doi: 10.1110/ps.051484505

Banko MI, Krzyzanowski MK, Turcza P, Maniecka Z, Kulis M, Kozlowski P (2013) Identification of amino acid residues of ERH required for its recruitment to nuclear speckles and replication foci in HeLa cells. PloS one 8: e74885 doi: 10.1371/journal.pone.0074885

Fujimura A, Kishimoto H, Yanagisawa J, Kimura K (2012) Enhancer of rudimentary homolog (ERH) plays an essential role in the progression of mitosis by promoting mitotic chromosome alignment. Biochemical and biophysical research communications 423: 588-592 doi: 10.1016/ j.bbrc.2012.06.018

Harigaya Y, Tanaka H, Yamanaka S, Tanaka K, Watanabe Y, Tsutsumi C, Chikashige Y, Hiraoka Y, Yamashita A, Yamamoto M (2006) Selective elimination of messenger RNA prevents an incidence of untimely meiosis. Nature 442: 45-50 doi: 10.1038/nature04881

Hazra D, Andric V, Palancade B, Rougemaille M, Graille M (2020) Formation of S. pombe Erh1 homodimer mediates gametogenic gene silencing and meiosis progression. Scientific reports 10: 1034 doi: 10.1038/s41598-020-57872-4

Hiriart E, Vavasseur A, Touat-Todeschini L, Yamashita A, Gilquin B, Lambert E, Perot J, Shichino Y, Nazaret N, Boyault C, Lachuer J, Perazza D, Yamamoto M, Verdel A (2012) Mmi1 RNA surveillance machinery directs RNAi complex RITS to specific meiotic genes in fission yeast. The EMBO journal 31: 2296-2308 doi: 10.1038/emboj.2012.105

Jin T, Guo F, Serebriiskii IG, Howard A, Zhang YZ (2007) A 1.55 A resolution X-ray crystal structure of HEF2/ERH and insights into its transcriptional and cell-cycle interaction networks. Proteins 68: 427-437 doi: 10.1002/prot.21343

Jonas S, Izaurralde E (2013) The role of disordered protein regions in the assembly of decapping complexes and RNP granules. Genes \& development 27: 2628-2641 doi: 10.1101/gad.227843.113 Kavanaugh G, Zhao R, Guo Y, Mohni KN, Glick G, Lacy ME, Hutson MS, Ascano M, Cortez D (2015) Enhancer of Rudimentary Homolog Affects the Replication Stress Response through Regulation of RNA Processing. Molecular and cellular biology 35: 2979-2990 doi: 10.1128/MCB.0127614 
Mikolaskova B, Jurcik M, Cipakova I, Kretova M, Chovanec M, Cipak L (2018) Maintenance of genome stability: the unifying role of interconnections between the DNA damage response and RNA-processing pathways. Current genetics 64: 971-983 doi: 10.1007/s00294-018-0819-7

Nakagawa T, Okita AK (2019) Transcriptional silencing of centromere repeats by heterochromatin safeguards chromosome integrity. Current genetics 65: 1089-1098 doi: 10.1007/s00294-019-00975$\mathrm{x}$

Pang K, Zhang Z, Hao L, Shi Z, Chen B, Zang G, Dong Y, Li R, Liu Y, Wang J, Zhang J, Cai L, Han X, Han C (2019) The ERH gene regulates migration and invasion in 5637 and T24 bladder cancer cells. BMC cancer 19: 225 doi: 10.1186/s12885-019-5423-9

Pogge von Strandmann E, Senkel S, Ryffel GU (2001) ERH (enhancer of rudimentary homologue), a conserved factor identical between frog and human, is a transcriptional repressor. Biological chemistry 382: 1379-1385 doi: 10.1515/BC.2001.170

Sugiyama T, Thillainadesan G, Chalamcharla VR, Meng Z, Balachandran V, Dhakshnamoorthy J, Zhou M, Grewal SIS (2016) Enhancer of Rudimentary Cooperates with Conserved RNA-Processing Factors to Promote Meiotic mRNA Decay and Facultative Heterochromatin Assembly. Molecular cell 61: 747-759 doi: 10.1016/j.molcel.2016.01.029

Tsubota SI, Phillips AC (2016) Drosophila Enhancer of Rudimentary Homolog, ERH, Is a Binding Partner of RPS3, RPL19, and DDIT4, Suggesting a Mechanism for the Nuclear Localization of ERH. Molecular biology international 2016: 8371819 doi: 10.1155/2016/8371819

Wan C, Tempel W, Liu ZJ, Wang BC, Rose RB (2005) Structure of the conserved transcriptional repressor enhancer of rudimentary homolog. Biochemistry 44: 5017-5023 doi: 10.1021/bi047785w Weng MT, Lee JH, Wei SC, Li Q, Shahamatdar S, Hsu D, Schetter AJ, Swatkoski S, Mannan P, Garfield S, Gucek M, Kim MK, Annunziata CM, Creighton CJ, Emanuele MJ, Harris CC, Sheu JC, Giaccone G, Luo J (2012) Evolutionarily conserved protein ERH controls CENP-E mRNA splicing and is required for the survival of KRAS mutant cancer cells. Proceedings of the National Academy of Sciences of the United States of America 109: E3659-3667 doi: 10.1073/pnas.1207673110

Weng MT, Luo J (2013) The enigmatic ERH protein: its role in cell cycle, RNA splicing and cancer. Protein \& cell 4: 807-812 doi: 10.1007/s13238-013-3056-3

Weng MT, Tung TH, Lee JH, Wei SC, Lin HL, Huang YJ, Wong JM, Luo J, Sheu JC (2015) Enhancer of rudimentary homolog regulates DNA damage response in hepatocellular carcinoma. Scientific reports 5: 9357 doi: 10.1038/srep09357

Wojcik E, Murphy AM, Fares H, Dang-Vu K, Tsubota SI (1994) Enhancer of rudimentaryp1, e(r)p1, a highly conserved enhancer of the rudimentary gene. Genetics 138: 1163-1170 doi:

Xie G, Vo TV, Thillainadesan G, Holla S, Zhang B, Jiang Y, Lv M, Xu Z, Wang C, Balachandran V, Shi Y, Li F, Grewal SIS (2019) A conserved dimer interface connects ERH and YTH family proteins to promote gene silencing. Nature communications 10: 251 doi: 10.1038/s41467-018-08273-9 Zafrakas M, Losen I, Knuchel R, Dahl E (2008) Enhancer of the rudimentary gene homologue (ERH) expression pattern in sporadic human breast cancer and normal breast tissue. BMC cancer 8: 145 doi: $10.1186 / 1471-2407-8-145$

Zhang D, Chu YJ, Song KJ, Chen YL, Liu W, Lv T, Wang J, Zhao H, Ren YZ, Xu JX, Xia NN, Li HX, Yao Q (2020) Knockdown of enhancer of rudimentary homolog inhibits proliferation and metastasis in ovarian cancer by regulating epithelial-mesenchymal transition. Biomedicine \& pharmacotherapy = Biomedecine \& pharmacotherapie 125: 109974 doi: 10.1016/j.biopha.2020.109974 Zofall M, Yamanaka S, Reyes-Turcu FE, Zhang K, Rubin C, Grewal SI (2012) RNA elimination machinery targeting meiotic mRNAs promotes facultative heterochromatin formation. Science 335: 96-100 doi: 10.1126/science. 1211651 


\section{Cellular roles of ERH/Erh1 homodimers}

human

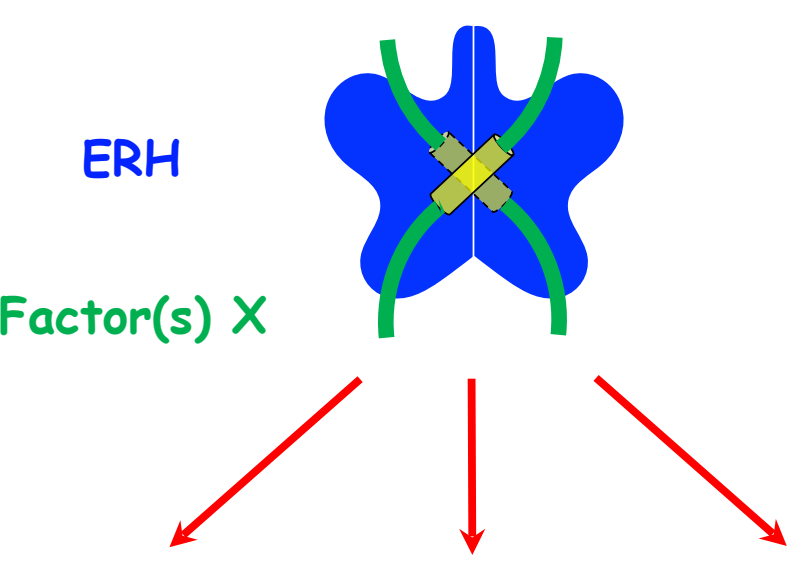

RNA processing (transcription, splicing,...)
DNA replication other $\&$ repair ?

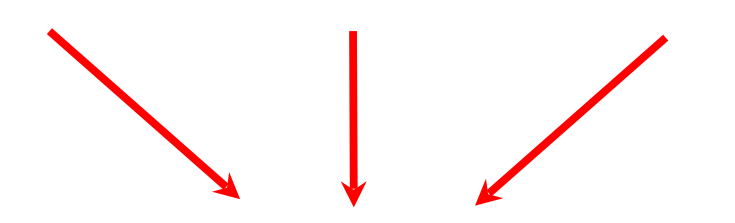

Cell division Genome stability Cell migration Tumorigenesis fission yeast $S$. pombe
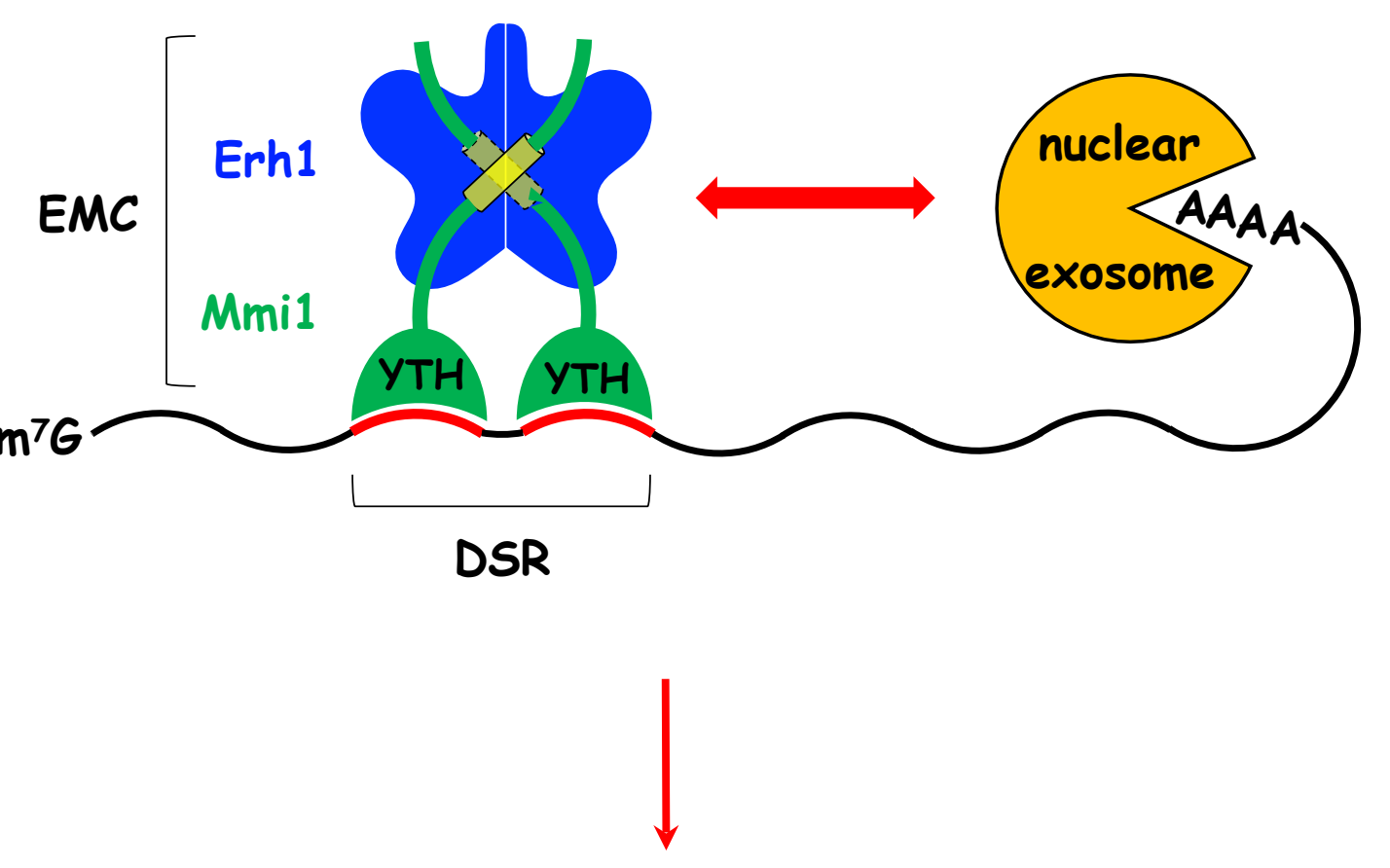

meiotic mRNA degradation 